\title{
Ethnic Accommodation and Electoral Rules in Ethno-Geographically Segregated Societies: PR Outcomes Under FPTP in Myanmar Elections
}

\author{
Joel Selway
}

\begin{abstract}
In this article I explore how the current first-past-the-post (FPTP) rules contributed to the failure of ethnic compromise during the democratic period (1948-1962) in Myanmar by encouraging extremist parties, hardening ethnic divisions, and causing political deadlock, ironically the same charges the centripetal school lays against proportional representation (PR). This puzzle of "PR outcomes" under FPTP is explained using geographic information systems techniques that map the country's 2010 electoral districts onto an ethnic population map. It shows that ethnic party success in the 2010 election closely follows the distribution of ethnic groups in Myanmar and that given the high level of ethno-geographic segregation in Myanmar the representation of ethnic parties would be similar under PR and the alternative vote to the current FPTP. I conclude by discussing Indonesia's electoral rules as a possible solution for Myanmar. The general theoretic contribution is that, although past scholars have generally argued that FPTP is bad for ethnically divided societies, their mechanisms are incorrect for ethnogeographically segregated societies. Keywords: Myanmar, Burma, democracy, elections, ethnicity
\end{abstract}

WHICH ELECTORAL RULES ARE BEST FOR PRODUCING ETHNIC ACCOMMODATION in divided societies? Answering this question is crucial to newly democratizing countries, such as Myanmar, where ethnic accommodation can determine the very survival of democracy. Indeed, Myanmar is currently debating a change in electoral rules in parliament. ${ }^{1}$ Two major schools of thought, the consociational and centripetal schools, ${ }^{2}$ each claim to best address this issue. The consociational school claims that maximizing representation will best accommodate ethnic diversity (Lijphart 1990, 2004; Reilly 2001, 2002, 2011a, 2011b; Bogaards 2008; Taylor 2009). There are several political institutions that help achieve this, one of which is proportional representation (PR) electoral rules that award seats to par- 
ties commensurate with the percent of votes secured in elections. ${ }^{3}$ In contrast, the centripetal school (Horowitz 1985, 1994; Reilly 2001, 2002, 2011a, 2011b) seeks to build multiethnic (or ethnic-free) parties or coalitions that emphasize "aggregative, centrist and inter-ethnic politics" (Reilly 2011a, 4). Centripetal electoral rules, the most heavily emphasized of which is the alternative vote $(\mathrm{AV})$, are hypothesized to provide incentives for pre-electoral collaboration by encouraging voting across ethnic lines within a constituency (Horowitz 1985; Reilly 2006). ${ }^{4}$

Each school, naturally, criticizes the other's approach. Centripetalists argue that maximizing representation simply solidifies ethnic divisions into the political system, encourages extremist parties (Powell 1982, 92-96), hardens ethnic divisions (Cox 1990), and causes deadlock (Jarstad 2008; Reilly and Reynolds 1999, 29-31; Roeder and Rothchild 2005). Consociationalists argue that centripetalist rules are complicated for voters to understand and at best ensure that a candidate is elected by a majority (Horowitz 1994). Both schools seem to be in agreement on one thing: first-past-the-post (FPTP) in single-member districts is harmful to the goal of ethnic accommodation because of the danger that the largest group will win a disproportional number of seats (Horowitz 1985, 638-650). Indeed, Diamond goes as far as stating, "If any generalization about institutional design is sustainable . . . it is that majoritarian systems are ill-advised for countries with deep ethnic, regional, religious, or other emotional and polarizing divisions"; the concern is "indefinite exclusion from power of any significant group" brought about by disproportionality (Diamond 1999, 194).

I test a simple theoretical proposition: How ethnic groups are geographically distributed within divided societies determines the effect of electoral rules on ethnic accommodation. Specifically, the geographic segregation of ethnic groups renders very similar outcomes for the three aforementioned types of electoral rules-FPTP, PR, and AV. I test this theory by examining two periods in Myanmar's ${ }^{5}$ electoral history. First, I show how FPTP in Myanmar's democratic era (1948-1962) ${ }^{6}$ led to the failure of ethnic accommodation, not because of disproportionality, but rather because of proportionality and the accompanying manifestation of three standard critiques directed at PR: encouraging extremist parties, hardening ethnic divisions, and causing political deadlock. During this period, minority ethnic groups were adequately represented in parliament. However, the ethnic parties/factions were not of the moderate type predicted by consociationalists and constantly fought over government resources and other ethnically targeted policies. In short, we get PR outcomes under FPTP rules in an ethno-geographically segregated country. 
Second, I explore ethnic voting in the 2010 and 2012 elections. Relying on a new technique to estimate ethnic diversity at the constituency level using geographic information systems (GIS) procedures, I show that ethnic divisions have quickly returned under FPTP electoral competition. If elections, scheduled for late 2015, were to be completely free and fair and to continue under FPTP, we should expect an increase in the number and success of ethnic parties and a return to the types of ethnic demands that underlay the political deadlock and rise of extremist parties in the democratic era. I also use these constituency-level demographic estimates to calculate hypothetical scenarios under both PR and $\mathrm{AV}$, showing that the outcomes in terms of representation of ethnic parties would be similar.

In short, this is an argument about equifinality. Different systems yield similar levels of ethnic representation. The key factor is the geographic segregation of ethnic groups, which makes it nigh impossible to draw electoral boundaries that might lead to more unifying outcomes for either AV or FPTP. Instead, most races end up being intra-ethnic and minority groups thus win close to proportional representation under each rule. While past scholars have briefly noted my specific claim about electoral rules and the geographic segregation of ethnic groups (Horowitz 1985; Bogaards 2003; Huber 2012), the theoretical logic has not been developed in detail or tested empirically. In addition to this theoretical and empirical contribution, my account adds to the historical understanding of Myanmar's democratic era. By combining the theoretical lens developed in this article with secondary historical evidence, I produce new insight that the electoral system was more at fault for the failure of democracy during this period than past accounts have allowed. It should thus be of interest to Myanmar scholars.

Given the argument I make here, it is thus frustrating that Myanmar is currently debating the adoption of PR electoral rules when what should be the most important outcome, ethnic accommodation - whose failure led to the coup in the first place - will be similar to what it has been under the current system, at least from the standpoint of the electoral rules. Several scholars and political figures have made specific calls for PR, arguing that it will increase representation of smaller, ethnic political parties while reducing the seat inflation of larger parties - the standard consociational logic (Marston 2013; Chit 2014; Smith n.d.). I show that only the smallest of ethnic groups would gain significantly more representation under PR, and demonstrate that more representation is not what the country needs anyway. If protection for minorities is a goal of the political system, electoral rules are not the policy solution. 


\section{Electoral Rules and Ethnic Accommodation in Ethno-Geographically Segregated Societies}

At least as far back as Duverger (1954), political scientists have understood that electoral rules and social structure interact. Duverger's Law, often remembered for its institutional logic concerning majoritarian systems tending toward a two-party system, actually posits that social factors are the primary driver of the party system; electoral rules simply act as a "brake or accelerator." These social factors include "tradition and history, social and economic structure, religious beliefs, racial composition, national rivalries, and so on" (Duverger 1954, 203). In recent crossnational tests of Duverger's Law, scholars have interacted measures of ethnic and religious heterogeneity as proxies for these social factors, recognizing the contextual effect of electoral rules (Amorim Neto and Cox 1997; Ordeshook and Shvetsova 1994; Clark and Golder 2006; Stoll 2008).

The regional pattern of political support was specifically recognized by Duverger as an exception to his theory. Citing the examples of Denmark, Sweden, and Canada, he concludes that in majoritarian systems, when competing parties are different in different regions of the country, the party system at the national level will tend to more than two parties (Duverger 1954, 221-223). Duverger did not go into detail about what shapes such differing competition. Both Rae (1971) and Sartori (1986), however, posit that when minorities (ethnic, linguistic, or other) are geographically concentrated, plurality systems will not abide by Duverger's two-party law.

Cox (1997), referring to this phenomenon of different parties' running in different regions as party aggregation, suggests that type of social structure more generally is key. Drawing on past work by Ordeshook and Shvetsova (1994), he posits that the effective number of ethnic groups in a society matters for party aggregation. In a homogeneous country, aggregation is much more likely. Heterogeneous countries will have more, presumably ethnic-based, parties, only some of which compete in some areas of the country. Building on this, two studies on party systems in Africa argue that ethno-geographic segregation also matters (Mozaffar, Scarritt, and Galaich 2003; Brambor, Clark, and Golder 2007), echoing arguments made by Sartori and Rae. When ethnic groups are segregated in their own geographic regions, there is increased upward pressure on the number of parties. More recently, Lublin (2014, 2015) and Maeda (2013) test this in global datasets and draw similar conclusions. ${ }^{7}$ 
This literature on the number of parties is representative of the direction that the study of the effect of electoral rules on ethnic accommodation should take more firmly. Above, I presented the two main schools of thought. What they share in common is their focus on "divided societies." The presumption in much of the writing is that all divided societies are the same. For example, Lijphart $(2004,75)$ states clearly that "in such deeply divided societies the interests and demands of communal groups can be accommodated only by the establishment of power sharing." Later, admitting that "while the power-sharing model should be adapted according to the particular features of the country at hand, it is not true that everything depends on these individual characteristics," (Lijphart 2004,45 ), he proceeds to strongly recommend PR electoral rules for all divided societies.

This basic caricature of the ethnic accommodation literature masks the many authors who, mostly in single-country studies, are sensitive to "particular features of the country at hand." For example, Barkan (1995, 1998) claims that ethnic minorities have achieved "proportional" representation despite FPTP in various African cases due to geographic patterns of settlement and cleavage formation. ${ }^{8}$ More recently, Ziegfeld (2013), looking at the cases of India and Israel, concludes that when a small party's votes are highly geographically concentrated, then changes in district magnitude have very little impact on its levels of representation. Lublin's (2014) careful cross-country analysis confirms these findings more broadly. ${ }^{9}$

This study builds on these past insights. Specifically, I argue that FPTP in Myanmar did not fail because of the most common critique leveled against it: disproportionality, which stems from the danger of the largest group literally taking every seat in a winner-take-all system. This is only possible, however, if ethnic groups are identically distributed in every constituency and either the largest has a majority ( $>50$ percent) or the minority groups are unable to coordinate..$^{10}$ If parties are ethnically based, however, and segregated into their own regions, minority groups will be the largest groups in their regions. Disproportionality, therefore, is not as big a concern. ${ }^{11}$ Rather, FPTP failed for the same critiques the centripetal school makes about PR in such societies: the translation of ethnic divides into the legislature; ethnic parties' having no incentive to moderate or join with other ethnic parties; ethnic parties' playing up identity issues in order to encourage their group members to vote along identity lines; and ethnic parties' fighting over resources in the legislature to benefit their group. In short, there is no mechanism to induce voters to throw support behind a non-coethnic candidate or party. 
Ethno-geographic segregation also nullifies the benefits of AV. AV's advantage comes by enabling voters to rank candidates of other parties. Thus, although they may rank their coethnic first, they get to rank candidates from other groups also. This gives candidates from other groups incentives to moderate their stances in order to obtain a favorable ranking from non-coethnic voters (Reilly 2001). However, in ethno-geographically segregated societies there simply are no non-coethnic candidates to rank. Thus, the same outcomes emerge as under FPTP and PR.

\section{The Democratic Era in Myanmar (1948-1962)}

The case of Myanmar enables us to test whether FPTP led to ethnic discontent due to disproportionality or precisely because of proportionality. If disproportionality were the main reason for ethnic discontent, I would expect to see minority parties not getting the appropriate number of seats given their size. This should be accompanied by plenty of evidence that minority parties were complaining of disproportionality. In addition, dynamics in the legislature should be dominated by disagreements over issues relevant to mostly the majority ethnic group. There would be little voice for minority groups. In contrast, if proportionality were the issue we should expect to see ample minority representation and articulation of concerns in the parliament. Such translation of ethnic divides should lead to gridlock on various issues. Lastly, insurgent groups should be more concerned about such issues than about representation.

Ethnic discontent is widely recognized as a factor in the failure of democracy in Myanmar, then known as Burma, in the 1948-1962 period, but the focus has been mostly the ethno-federal structure and the subsequent extralegal insurgencies. The goal of this narrative is not to replace these important parts of the narrative regarding the breakdown of democracy in Myanmar. Rather, it is to highlight that ethnic discontent was unable to be solved in the parliament, the legally constituted forum for discussing the major question of the postindependence era regarding how much autonomy various ethnic groups would enjoy. After providing important sociological and historical context, I proceed chronologically, discussing the ethnic composition of parliament after each election in this period and the ethnic dynamics that ensued.

\section{Background}

Myanmar is a highly ethnically diverse country. The majority group is the Burmans who constitute approximately 55-68 percent of the popula- 
tion. ${ }^{12}$ The Karen are the second most populous ethnic group, at about 9-14.6 percent. Next are the Shan, which estimates put at about 8-9 percent of the population. Other major ethnic groups are the Rakhine (3.5-5 percent), Mon (2-8 percent), Chin (2-6.3 percent), Kachin (1.5-3.1 percent), and Rohingya ( 2 percent).${ }^{13}$ Exact sizes of ethnic groups are heavily disputed and some groups are simply not recognized. It is virtually impossible to give an accurate representation of these figures without a new, unbiased census. In 1947, as Myanmar's first constitution was being written, the Karen pushed for 25 percent of seats in the Constituent Assembly. Indeed, estimates of the country's overall population size vary by as much as 22 million. The last official census was in 1983, but since large areas of the country were inaccessible to the government due to the civil war, ethnic group sizes are unreliable; and though there was reportedly a census in 2007 , the same inaccessibility problem would have been present, nor have the results been made accessible to date..$^{14}$

These major ethnic groups are quite heavily segregated in their own regions of Myanmar. As Figure 1 shows, the Burmans populate the heartland of Burma and the west side of the most southern strip (Tenasserim). At the outskirts of this region Burmans are mixed with populations of the minority groups-Mon in Tenasserim, Karen in the south (Irrawady and Pegu districts), and Shan in the northeast-before reaching the respective minority heartlands situated at the borderlands of the country. Regional boundaries (not shown) are drawn around these ethnic groups for the most part. The northeastern states (Shan and Kachin) are the most diverse, but there are notably few Burmans. The Karen are the most divided by regional political borders, with the nominal Karen state incorporating less than half of the whole Karen population.

The Mon, Burman, Shan, and Rakhine ethnic groups in Myanmar historically ruled over independent kingdoms in the region, each being ascendant during various periods since about the eleventh century (SarDesai 1997). When the British first arrived in the region at the beginning of the nineteenth century, the Burmans were on top, having overpowered all the other ethnic groups into various degrees of submission. Against this historical backdrop, the British administration of Myanmar, then known as Burma, would further set the stage for later ethnic disputes and accompanying territorial disagreements. The British conquered Burma in stages and unevenly, leading to differing forms of administration throughout the territories that would become Burma. "Burma Proper" was directly administered by the British and included the Burman, Mon, and Rakhine areas. The Chin and Kachin hills along with the Salween district (today part of the Karen state) were ruled indirectly and 
known as the Frontier Areas. The Shan areas became a British protectorate and were known as the Federated Shan States. Karenni, named after the area's dominant Karen subgroup, was recognized as a sovereign state. Thus, the task of independence entailed simultaneously uniting these disparate administrative areas as well as throwing off British rule (Smith 1999).

Ethnicity became an increasingly salient dividing factor during British rule within Burma Proper. Under a divide-and-conquer strategy, the British placed minority ethnic groups in positions of political power and advantaged them in the economic realm. Taylor (1987, 128-129) writes, "there was almost an inverse relationship between the size of the various ethnic groups and their hold on political and economic power during the late colonial period." On top of this, religious conversion further differentiated the ethnic groups, with large proportions of the Karen, Kachin, and Chin converting to Christianity. When the Japanese advanced south during World War II, the sidelined Burmans jumped at the chance to help oust the British, exacting revenge on minority groups in the process. These ethnic grievances would play out during difficult independence negotiations with the British in the postwar era.

After World War II, the British quickly began independence discussions. Throughout this process, the majority Burmans dominated the negotiations through the Anti-Fascist People's Freedom League (AFPFL), a political party held together by the leadership of Aung Sang. Other ethnic groups were largely sidelined. The Burmans secured the cooperation of other minority groups, specifically the Shan, Chin, and Kachin, with the historic Panglong Agreement in 1947, which made promises such as future independence and administrative and financial autonomy. ${ }^{15}$ The Karen, Mon, and Rakhine were noticeably absent (Taylor 1987).

The major Karen leaders and parties, moreover, would go on to boycott elections to the Constituent Assembly, which would produce the 1947 constitution. The AFPFL won 173 out of 210 contested seats in the elections for the Constituent Assembly. Such a landslide victory is quite typical in newly independent countries where AFPFL-like organizations (popular fronts composed of numerous parties and factions) later fragment into separate units. In the case of Myanmar, the AFPFL's unified front was to convince the British that independence would not result in political instability. But with the pressures of independence negotiations no longer relevant, the 1951-1952 election quickly began to reveal the ethnic divisions within the legislature. 
Figure 1 Map of Ethnic Groups in Myanmar and 2010 Constituency Boundaries

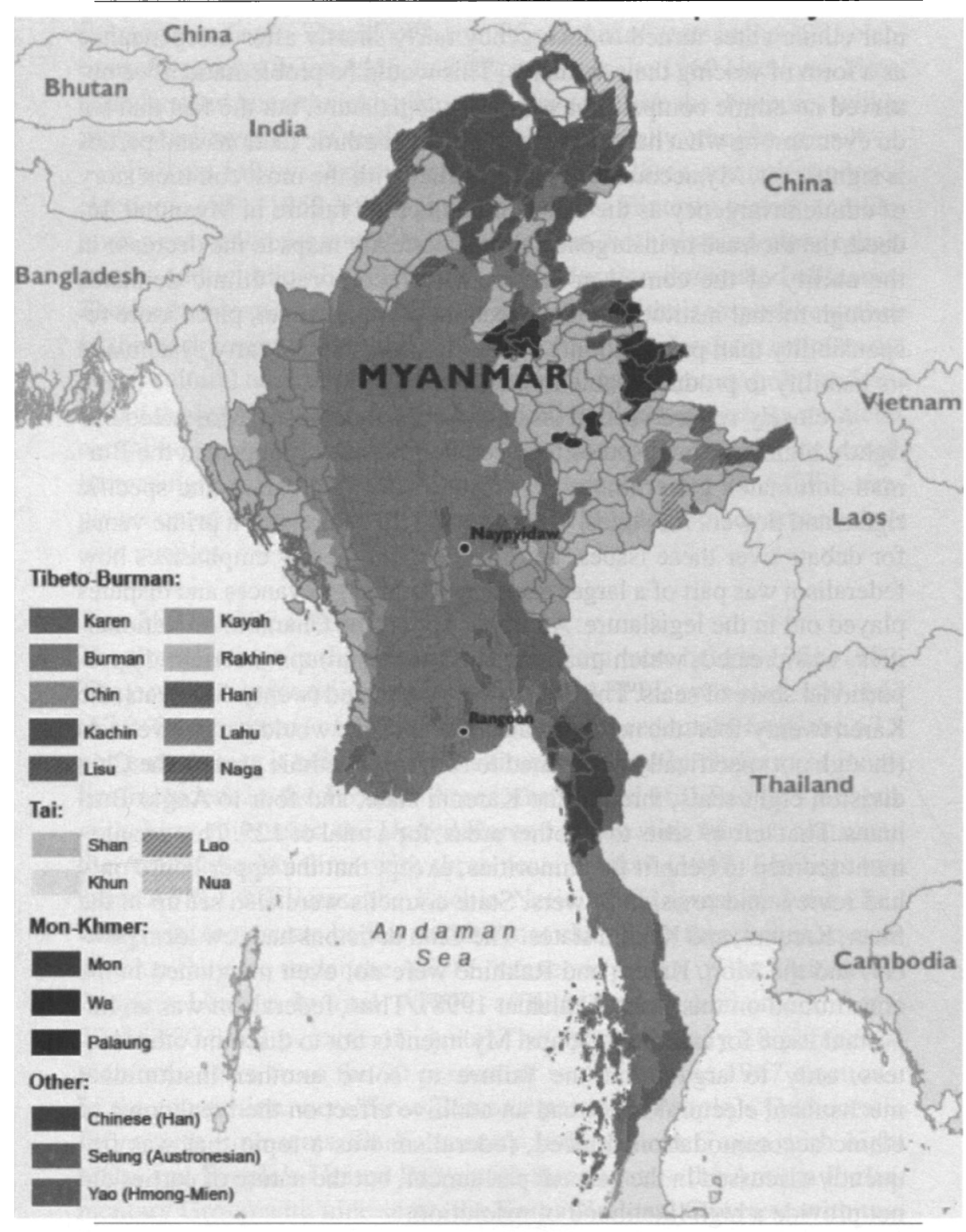

Source: Author's creation based on Tinker (1967); Smith (1999); and AltseanBurma, Elections and Ethnic Representation (2012), (www.altsean.org/Research /2010/Key\%20Facts/Constituencies/Constituencies.php). 
Three competing explanations concerning Myanmar's ethnic tensions in the 1948-1962 period must be addressed: insurgency, federalism, and the existence of multiethnic alliances. First, many of the most popular ethnic elites turned to insurgency fairly shortly after independence as a form of voicing their demands. This would be problematic if we observed no ethnic competition within the legislature, but the fact that we do even among what have been called weaker ethnic factions and parties is significant. My account does not conflict with the most common story of ethnic insurgency as the cause of democratic failure in Myanmar. Indeed, the increase in insurgency almost perfectly maps to the decrease in the ability of the central government to incorporate ethnic demands through formal institutions. This account does, however, place more responsibility than past accounts on the shoulders of the party system and its inability to produce stable multiethnic coalitions.

A closely related second issue is that of federalism. Most accounts rightly highlight the disputes between the minority groups and the Burman-dominated government over issues of state creation and specific rights and powers for states. The national legislature was a prime venue for debate over these issues, and this account merely emphasizes how federalism was part of a larger package of ethnic grievances and disputes played out in the legislature. An upper house, the Chamber of Nationalities, was created, which guaranteed minority groups a certain disproportional share of seats. The Shan were guaranteed twenty-five seats, the Karen twenty-four, the newly created Kachin state would get twelve seats (though not specifically designated to the Kachin ethnic group), the Chin division eight seats, three to the Karenni state, and four to Anglo-Burmans. That left 49 seats to all other areas, for a total of 125 . This arrangement seemed to benefit the minorities, except that the upper house only had review and revision powers. State councils were also set up in the Shan, Karenni, and Kachin states. The Chin divisions had few local powers, and the Mon, Karen, and Rakhine were not even mentioned in the constitution on this front (Callahan 1998). Thus, federalism was an important issue for minority groups. My intent is not to discount other factors, only to argue that the failure to solve another institutional mechanism, electoral rules, had an additive effect on the breakdown of ethnic accommodation. Indeed, federalism was a topic that was frequently discussed in the nascent parliament, but the nature of parties did not provide a high likelihood of resolution.

A third issue is that the main Burman-dominated party, the AFPFL, had pretentions to be multiethnic. In reality, the multiethnic part of the AFPFL was merely a short-lived coalition of ethnic groups thrown to- 
gether at each election rather than a true multiethnic party. Indeed, much of the most interesting ethnic political dynamics happened within the dominant party. Allied parties often left before the next elections and infighting was fierce. The AFPFL won 85 percent of seats in the 1951 elections, 58 percent in the 1956, and 63 percent in the 1960 elections. Thus, to understand interethnic dynamics we must analyze the dynamics within the governing party as well as among the nominally ethnic parties. ${ }^{16}$

In what follows, I show that in each of the three postindependence elections, 1951-1952, 1956, and 1960, ethnic minority parties and factions were well represented in the parliament, both as stand-alone ethnic parties and within the AFPFL and other Burman-dominated alliances. These ethnic parties scrambled over resources for their respective groups in the parliament, and ethnic issues, including federalism, ministerial posts, cultural and religious policies, as well as budgetary politics dominated the legislative discussions. In addition, these seemingly multiethnic alliances were fragile and ethnic parties frequently defected. Increasingly, minority parties turned to insurgency, but the AFPFL simply co-opted weaker ethnic parties that had little legitimacy among their own peoples.

\section{The 1951-1952 Elections}

The first elections in the postindependence era were held in 1951-1952. They were a resounding success for the AFPFL, winning 143-147 (57.2-58.8 percent) of 250 seats. ${ }^{17}$ This was a reduction from the 67.8 percent of seats it held in the Constituent Assembly. Support of its allies included, in the Frontier Areas, the United Hill People's League with thirty-nine seats, the United Karen League with thirteen seats, and the Arakanese Muslims with three seats. Tinker $(1967,66)$ lists two more AFPFL affiliates, the Kachin National Congress and the Chin Congress, as separate bodies, but it is not clear from the various sources whether they ran under the AFPFL banner or as part of the United Hill People's League. In total, AFPFL affiliate parties won an additional 52-55 (20.8-22 percent of) seats. The approximately 80 percent of seats was down from the 90 percent of seats from the 1947 elections. In the opposition were three Burman parties-People's Democratic Front with nine seats, Parliamentary Independent Group with eight seats, and People's United Party with three seats - the Arakan Parliamentary Group with nine seats, the Karen National Congress with two seats, the $\mathrm{Pa}-\mathrm{O}$ (a cousin of the Karen that resides in the Shan state) Organization with three seats, and five independents from Arakan state (likely of Rakhine ethnicity). 
The 10 percent reduction in AFPFL support came primarily from the defection of the Rakhine ethnic group. In a 1950 by-election, an independent ethnic Rakhine, Kyaw Min, defeated the AFPFL candidate; by the 1951-1952 general elections, all but three of the seventeen Rakhine constituencies rejected AFPFL candidates. Shortly after the elections, the three other Rakhine candidates that ran had under the AFPFL banner joined their co-ethnics in the Independent Arakanese Parliamentary Group (IAPG). Their stated primary goal was a separate Rakhine state within the union (Tinker 1967, 68; Smith 1999, 244).

Dynamics within the Kachin state legislative assembly would lead to a division of Kachin support at the national level for the AFPFL. In the Kachin state elections, fourteen Kachin MPs were elected, plus another five AFPFL ethnic Burman candidates. The AFPFL decided to throw its backing behind one of the two competing leaders for the Kachin ethnic cause, thereby splitting the fourteen seats down the middle and effectively granting AFPFL twelve of the nineteen seats. This politicking at the state level led one of the leaders to create their own party, the People's Economic and Cultural Development Organization (PECDO) in 1953 (Tinker 1967, 73). PECDO's main platform was the industrialization of the Kachin state, which agenda would carry into discussion in the Chamber of Deputies. More importantly, PECDO would subsequently compete separately from the AFPFL in national elections.

The Shan were co-opted in a slightly different fashion, having negotiated the best pre-independence bargain. In addition to the creation of a united Shan state and the option of secession after a minimum of ten years in the new Burma Union, the Shan elite were allowed to maintain traditional control of their state, just as they had under both the British and Japanese. Elections were not even held in wide areas of the state, relying instead upon the traditional leaders, or Sawbwas, to select MPs from among themselves. This attempt at an interethnic alliance would again backfire on the AFPFL. As Shan groups emerged that opposed and replaced the feudal leadership of the Sawbwas they became naturally anti-AFPFL, seeing the Burmans as simply another layer in an oppressive and outdated feudal system (Tinker 1967, 72).

Most of the Karen had previously remained separate from the AFPFL in the 1947 elections. The Karen Central Organization split into the Karen National Union, which boycotted the elections and turned to insurgency, and the Karen Youth Organization (KYO), which won nineteen seats. A further five Karen ran and won seats as independents and backed the AFPFL (Cady 1958, 551). 
For the time being, however, the AFPFL would maintain some semblance of a multiethnic veneer, still winning 60 percent of the vote and 85 percent of seats. Other parties affiliated with the AFPFL, either running under the AFPFL banner or separately, included the Kachin National Congress, the Union Karen League, the Chin Congress, the United Hill People's Congress, and the Burma Muslim Congress (Tinker 1967, 66). Its massive majority, however, hides the serious disagreements that had already emerged within the party. For example, there was much dispute within the government over the appointment of ministers. Prime Minister U Nu refused to appoint the Chin Council's nomination of Za Hre Lian as minister. Similarly in 1948, U Nu reversed the decision of the Shan Council to elect Tun Myint as head of the Shan state (Tinker 1967, 82). Whether for personal reasons or to explicitly undermine the minority groups, the actions of $\mathrm{U} \mathrm{Nu}$ in the appointment of ministers highlight the volatile nature of the coalition with pre-electoral promises being reneged with ease.

Slighted by these and other Burman-serving policies, the minority partners began demanding more and more concessions. As Smith writes, "Thus to carry out the daily business of Parliament, the AFPFL increasingly came to depend on individual bargains and agreements, of often labyrinthine complexity, with various political coalitions, particularly of elected minority representatives" (Smith 1999, 124). These bargains and agreements centered around three major issues: increased autonomy, public goods, and religious equality.

First, the negotiations around autonomous states within Myanmar depict the clear ethnic demands made by the minority groups in the legislature as well as the attempts by the Burman majority to extract as many concessions as possible from the process. In 1952, parliament created the state of Kayah by adding the Karen-inhabited former Shan state of Mong Pai to the existing Karen-dominated state (Karenni) and simply renaming it. Most scholars agree that the main purpose of creating Kayah was to pit the various Karen subgroups against each other. As the biggest potential numerical threat to the Burmans in the legislature, such divisive tactics would serve the Burmans politically (Smith 1999, 145-146; Cady $1958,640)$. First, the appellation Kayah referred to the name of the dominant subgroup within the newly created state, but not the largest Karen subgroup overall, the S'gaw Karen. Moreover, the added territory of Mong Pai was claimed by the S'gaw Karen, so this move not only thwarted the creation of a united and geographically larger pan-Karen state but also explicitly dealt a territorial loss to the S'gaw Karen. 
In an attempt to appease the Karen, the Burman-dominated government eventually created a second Karen state, Kayin. Nevertheless, this deal, which still dissatisfied the majority of Karen, ${ }^{18}$ came at the cost of halving the number of reserved seats in the two houses of parliament from forty-four to twenty-two and cutting Karen jobs in the civil and security forces (Smith 1999, 147). The Karen tried to push back - they wanted a state with a seaport to ensure future economic growth (Smith 1999,146 ), to incorporate the majority of their population (current state boundaries included only one-fourth of the Karen population), and some even demanded a Karen state stretching into mixed Burman-Karen areas as far as Rangoon, approximately half of the country of Myanmar ( $\mathrm{U} \mathrm{Nu}$ $1975,168)$ ! Even within the AFPFL, the Karen Youth Organization continued to demand larger state boundaries.

This interethnic haggling and unstable coalition is exactly the type predicted by the theory: ethnic groups concentrated in their own areas will vote explicitly along ethnic lines with these ethnic divisions being directly translated into the legislature. These ethnic parties will then form short-term alliances with the goal of extracting as many concessions for their ethnic group as possible until the coalition crumbles. By the first elections this was already a fitting description for Myanmar.

\section{The 1956 Elections}

By the 1956 elections, the AFPFL had disintegrated even further, such that they were no longer standing in each constituency and took just 145 seats ( 58 percent of 250 seats total, a drop of 27 percent) and 48 percent of the vote (a drop of 12 percent). This seat percentage was much closer to the nationwide proportion of the Burmans in the population. Shan parties, for the first time running separately from the AFPFL, took twenty seats (the United Hill People's Congress, fourteen; All Shan State Organization, four; Shan States Peasants Organization, two). They were initially still affiliated with the AFPFL, but when members of the AFPFLaffiliated All Shan States Peasant Organization began to be targeted by Shan insurgent groups, they all began to disaffiliate and refused to cooperate with the military (Smith 1999, 191), essentially falling into the opposition. Only one Karen subgroup, the $\mathrm{Pa}-\mathrm{O}$, took any seats, and just a single seat at that. The other Karen parties and the Chin and Mon parties, now completely co-opted by the AFPFL, simply ran under the AFPFL label (Smith 1999, 124, 147). ${ }^{19}$ The Kachin National Congress took two seats..$^{20}$

The opposition, led by the Burman-dominated (but nevertheless much smaller) National United Front (NUF), joined alongside some mi- 
nority parties, most notably the Arakan, which took fourteen seats, and the Burmese Muslim Congress (not listed as winning any seats, but could have run under the NUF banner) ${ }^{21}$ But the NUF was not a stable, multiethnic party capable of bringing about ethnic harmony. Its rapid fall in votes and seats in the succeeding elections perhaps is most indicative of its temporary nature, and Smith describes this Burman-dominated alliance as being "like the AFPFL of 1948 . . . a pragmatic alliance of different political factions and leaders who became necessarily adept at concealing their real intentions" $(1999,163)$. Smith's language suggests that even had the opposition NUF alliance been successful, no component party was committed to any kind of central, unified plan, as the name of the alliance erroneously suggested. This is exactly the prediction the theory generates for any coalition under FPTP in an ethno-geographically segregated society.

\section{The 1960 Elections}

The 1958 split of the AFPFL into two factions, the "Clean" AFPFL and the "Stable" AFPFL, further illustrates the ethnic dynamics in Myanmar as each Burman-dominated AFPFL faction tried to woo minority parties. $\mathrm{U}$ Nu's Clean AFPFL agreed to the creation of a new Arakan state in order to gain the support of the Arakan People's Liberation Party. He made the same promise to the Mon People's Front (Smith 1999, 176-177).

Ethnic parties took advantage of this split to increasingly vocalize their frustrations and disaffiliate from AFPFL. The three Mon politicians in parliament, for example, all ran as independents even as they were negotiating with U Nu's Clean AFPFL over statehood (South 2003, 121). Smith writes of these growing ethnic divisions in parliament:

Rather, it was part of a growing sense of frustration, expressed by virtually all the minority peoples in Burma, with the progressively more centralized and Burmanized form of government in Rangoon, which they protested was taking little account of their opinions or needs. This was reflected in some heated arguments in Parliament where MP's from the opposition Kachin National Congress, which had been allied with the AFPFL throughout the 1950s, kept up a sustained barrage of protests. (Smith 1999, 192) $)^{22}$

In addition to dropping out of the AFPFL, ethnic minorities were increasingly dropping out of mainstream politics and turning to insurgent tactics. 
Complaints over autonomy continued. Although the Arakan got their state, they began pushing for the legal separation of the Mayu Frontier division from Burma. The "largely ethnic Burman politicians in Rangoon" were making no concessions to the Karens (Smith 1999, 193). Another former AFPFL ally throughout the 1950s complained that little was being done for the insufficient powers accorded to the Karen under the 1947 constitution. The All Burma Karen Organization pushed in parliament for a new campaign and complete reinvestigation of the Karen cause. Chin parties complained that there was a lack of real autonomy (Smith 1999, 194).

Not just concessions for statehood lay at the heart of these complaints, but conflicts over the use of funds and religious rights. One of the Kachin National Conference's (KNC) major complaints was about "the appalling condition of the state's few roads, which had steadily deteriorated since the departure of the British" (Smith 1999, 192). Only 27 of the 174 miles of the state's only major road had been tarred or metaled. Chin parties in both the Clean and Stable AFPFL united to voice their grievances of "central government neglect of the hills" (Smith 1999, 194). Again, this neglect had to do with public goods: "not one high school had been built in the entire Chin Division in all the years since independence." (Tinker 1967). In 1954 there were 220 high schools in Burma (Tinker 1967, 197). At 1.5 percent of the population, the Chins should have had three of them. Clearly, the Burman-dominated parliament was neglecting its coalition partners.

Arakan and Mon MPs now began pushing for more Islamic rights (Smith 1999, 194). The Burmans had promulgated a state religion of Buddhism (Sahliyeh 1990). This was seen as more of an attack on the Karen, Chin, and Kachins who were heavily Christianized under the British, but who by this time had resolved themselves to armed conflict.

\section{Summary}

In sum, we see that FPTP electoral rules in a country where ethnic groups are geographically concentrated simply lead to the translation of ethnic divisions into the legislature. This was mostly in the form of Gunther and Diamond's congress parties. This translation, moreover, was manifested in explicit ethnic voting, ethnic parties, fragile ethnic coalitions, and politics that revolved around concessions for ethnic groups. In Myanmar we see attempts at multiethnic parties, but these were short-lived arrangements that were characterized by infighting over concessions for MPs' ethnic groups. In other words, they were not true ethnic parties. 
Voters only thought in ethnic representation terms and the AFPFL and NUF only ran candidates of the appropriate ethnic group in each constituency. As such, voters followed their co-ethnic MPs out of the AFPFL coalition when their demands were being ignored. Indeed, all of these component AFPFL parties were simply trying to maximize concessions for their ethnic groups in the short time the coalition was able to hold together. There was no unified policy platform upon which all, or even most, AFPFL coalition partners agreed on. Indeed, the AFPFL was as quick to seek out new minority partners as the existing partners left. These same ethnic-centered dynamics were seen even in the smaller opposition partner, the NUF. In short, policy outcomes were Burman dominated, causing minority parties to increasingly turn to extralegal means of voicing their demands. As MPs wrangled over these ethnic demands, the Burman-dominated government's ability to govern was ultimately hampered. In the aftermath of promising the Mon and Arakanese states, $\mathrm{U}$ Nu narrowly survived a vote of no confidence and had to pass the annual budget by presidential decree. Indeed, Steinberg (1982, 71-72) views $\mathrm{U}$ Nu's political agreement with minority groups as a major justification for military takeover in 1962.

\section{Recent Elections in Myanmar}

\section{The 2010 General Elections}

I have thus far demonstrated that FPTP in Myanmar encouraged extremist parties, hardened ethnic divisions, and caused political deadlock. An analysis of the 2010 elections enables me to estimate the extent of monoethnic constituencies and estimate the degree of cross-ethnic voting. Even if the 2010 and 2012 elections were not entirely free and fair, on which fact election observers and experts generally agree, ${ }^{23}$ do the voting patterns tell us anything about ethnic dynamics? Since no census has been made public since 1932, and certainly not on a constituency-level basis, I utilize a new method for estimating constituency-level ethnic structure in order to compare it with the 2010 electoral results. I attempt to answer three questions: Do we see evidence of ethnic voting? If so, does ethnic voting occur along predictable lines as structured by the ethno-institutional environment? How did the main Burman-dominated parties, the Union Solidarity and Development Party (USDP) and the National Democratic Force (an offshoot from the National League for Democracy, or NLD, who boycotted the elections), perform in minority ethnic group constituencies? 
Two scenarios are possible. First, given the pro- and antijunta divide in society, it is not likely that a single ethnic-Burman party will emerge. As such, multiethnic coalitions may be a necessity. Given the lack of incentives, both institutional and historical, to enter into pre-electoral coalitions or to create multiethnic parties, these coalitions would likely be the postelectoral, makeshift variety characteristic of the 1948-1962 era. The high level of inequality coupled with low level of development will likely lead to either political deadlock or unsustainable budget expendituresboth of which would lower the chances of a long-lived democracy.

If a dominant Burman party winning 55-68 percent of the seats in the legislature did arise, it would be unmatched in forming a government and unrivaled in policy favoring the majority ethnic group. If the minority parties are permanently shut out of the legislature in this manner, there is a high likelihood of returning to extralegal methods of getting their voices heard.

Forty parties were registered to compete in the lower house by the Electoral Commission. Only fifteen won seats. Of those fifteen, twelve were explicitly ethnic minority parties (see Table 1). Ethnic minority parties won just 14 percent of the elected seats (just under 11 percent of all seats) compared to the $32-45$ percent of the population that they constitute.

Table 1 Myanmar Election Results, 2010

\begin{tabular}{lccc}
\hline Party Name & \% Seats & \# Seats & \% Population \\
\hline Union Solidarity and Development Party & 78.48 & 259 & $\mathrm{n} / \mathrm{a}$ \\
Shan Nationalities Development Party & 5.45 & 18 & $8-9$ \\
National Unity Party & 3.64 & 12 & $\mathrm{n} / \mathrm{a}$ \\
National Democratic Force & 3.64 & 12 & $\mathrm{n} / \mathrm{a}$ \\
Rakhine Nationalities Development Party & 2.72 & 9 & $3-5.5$ \\
All Mon Region Democracy Party & 0.91 & 3 & $2-8$ \\
Pa-O National Organization & 0.91 & 3 & 1 \\
Chin National Party & 0.61 & 2 & $2-6.3$ \\
Chin Progressive Party & 0.61 & 2 & $2-6.3$ \\
Phaloon-Sawaw Democratic Party & 0.61 & 2 & $9-14.6$ \\
Wa Democratic Party & 0.61 & 2 & 1.3 \\
Unity and Democracy Party of Kachin State & 0.30 & 1 & $1.5-3.1$ \\
Kayin People Party & 0.30 & 1 & $9-14.6$ \\
Inn Nationalities Development Party & 0.30 & 1 & 0.1 \\
Taaung (Palaung) National Party & 0.30 & 1 & 1 \\
Other Party & 0.61 & 2 & $\mathrm{n} / \mathrm{a}$ \\
Directly Elected & 100 & 330 & \\
Appointed & & 110 & \\
Grand Total & & 440 & \\
\hline
\end{tabular}


Table 2 Vote by Party Type in 2010 Myanmar Elections

\begin{tabular}{lc}
\hline Party Type & \% Votes \\
\hline Pro-junta & 73.57 \\
Pro-junta (including nominally ethnic parties) & 74.50 \\
Pro-NLD & 8.43 \\
Third Way & 0.17 \\
Ethnic parties & 10.36 \\
\hline
\end{tabular}

To interpret these results, I first classify parties into pro-military, pro-NLD opposition parties, Third Way parties (claim neutrality between military and NLD), and ethnic parties..$^{24}$ The military's flagship party in the race, the USDP, is just one of several pro-military parties, the others being the National Unity Party (the military's flagship party in the 1990 elections), ${ }^{25}$ the 88 Generation Student Youths (Union of Myanmar), the New Era People's Party, the Union of Myanmar-Federation of National Politics, plus a few pro-junta ethnic parties: Kaman National Progressive Party, Rakhine State National Force, Unity and Democracy Party of Kachin State, and Wa Democratic Party. In total, pro-junta parties received 74.5 percent of the vote. There were six pro-NLD parties, the only one of significance being the National Democratic Force. ${ }^{26}$ These parties received 8.43 percent of the vote. Third Way parties only received 0.17 percent of votes. Ethnic parties not aligned with the military, however, received more votes than the pro-NLD parties and just over 10 percent.

Table 3 Vote by Ethnic Party in 2010 Myanmar Elections

\begin{tabular}{lccc}
\hline Ethnic Group & \% of Vote & \% Population & $\begin{array}{c}\text { \% Vote of } \\
\text { Group Population }\end{array}$ \\
\hline Shan & 2.5 & $8-9$ & $28-31$ \\
Rakhine & 3.01 & $3-5.5$ & $55-100$ \\
Chin & 0.52 & $2-6.3$ & $8-26$ \\
Mon & 0.74 & $2-8$ & $9-37$ \\
Karen & 1.4 & $9-14.6$ & $10-16$ \\
Wa & 0.16 & $1-1.5$ & $11-16$ \\
Lahu & 0.39 & $<1$ & $\sim 39$ \\
Kachin & 0.11 & $1.5-3.1$ & $4-7$ \\
\hline
\end{tabular}

Sources: Ethnologue (Lewis 2009), Joshua Project (US Center for World Mission 2008). 
Table 3 shows how the different ethnic parties fared compared to their size in the population. The Shan ethnic group, the country's second-largest minority after the Karen, received 55-62 percent of its group's vote. Shan parties got just under 5 percent of votes, even though they compose 8-9 percent of the population. The least successful ethnic parties were Karen ones. This analysis, however, does not take into account that elections were canceled in several minority areas. Thus, it likely underestimates the size of the ethnic vote. If we take away the USDP vote-assuming it is the result of rigging - and recalculate the percentages of the remaining parties in each constituency, ethnic parties double their vote, getting just over 20 percent of the total vote, or approximately two-thirds of the estimated non-Burman population. Expecting that some proportion of each ethnic group will be attracted to the other party types for various reasons, these figures suggest we can learn something about the pattern of ethnic voting from the 2010 elections in Myanmar. More details on this below.

\section{The Methodology: Georeferencing Electoral Districts on Ethnic Spatial Data}

What we want to know is where those votes for ethnic parties are compared to the distribution of ethnic groups among constituencies. This information is difficult to estimate in any country, but especially such a politically closed and economically developing one like Myanmar. Many countries collect ethnic data in censuses, although these data are almost never collected by electoral constituency. Fortunately, taking advantage of advances in geospatial software, we can calculate rough estimates of ethnic group sizes by constituency. I begin by mapping Myanmar's electoral districts in the ArcGIS software. I then overlay this map on top of a map with Myanmar's ethnic groups. ${ }^{27}$ These maps exist from several sources and to varying degrees of amalgamation. I combine data from two sources, Smith (1999) and Tinker (1967). In some areas, the ethnic maps show mixed ethnic groups. Having no further insight into the demographics of these areas, I simply assume these areas are split evenly. The map (Figure 1) shows which ethnic groups fall within a constituency and what area of land they cover. To calculate population size, I finally overlay a population density map on top. The software combines all three pieces of information and calculates a constituency population estimate for all ethnic groups found within its borders.

Using this method, I first produce nationwide population estimates for each ethnic group as follows: Burman, 32.8 million (68.7 percent); 
Table 4 Distribution of Ethnic Groups Across Constituencies

\begin{tabular}{|c|c|c|c|c|c|c|c|}
\hline & \multicolumn{6}{|c|}{ Size of Group } & \multirow[b]{2}{*}{$\begin{array}{l}\text { Majority } \\
(>50 \%)\end{array}$} \\
\hline & $0-9 \%$ & $10-25 \%$ & $26-49 \%$ & $50-65 \%$ & $66-80 \%$ & $81-100 \%$ & \\
\hline Burman & 47 & 17 & 41 & 23 & 6 & 154 & 183 \\
\hline Chin & 21 & 2 & 0 & 2 & 3 & 3 & 8 \\
\hline Kachin & 14 & 6 & 3 & 5 & 0 & 6 & 11 \\
\hline Karen & 26 & 13 & 17 & 27 & 1 & 8 & 36 \\
\hline Mon & 14 & 1 & 6 & 9 & 1 & 8 & 18 \\
\hline Other & 7 & 1 & 1 & 0 & 1 & 5 & 6 \\
\hline Rakhine & 2 & 0 & 0 & 1 & 0 & 17 & 18 \\
\hline Shan & 15 & 12 & 13 & 9 & 6 & 29 & 44 \\
\hline All Non-Burmans & 99 & 35 & 40 & 53 & 12 & 76 & 141 \\
\hline Total & 146 & 52 & 81 & 76 & 18 & 230 & 324 \\
\hline
\end{tabular}

Note: The categories are not mutually exclusive, so do not sum to the number of constituencies (328).

Karen, 5.1 million (10.7 percent); Shan, 4.1 million (8.5 percent); Rakhine, 2.7 million (5.7 percent); Mon, 1.9 million (4.1 percent); Kachin, 0.44 million ( 0.9 percent); and Chin, 0.33 million ( 0.7 percent). These estimates are very close to the proportions derived from other sources (see Table 3). But the most interesting data are at the constituency level. Fully 42 percent of constituencies are composed entirely of a single ethnic group: 325 of the 328 constituencies contained a majority ethnic group (i.e., more than 50 percent of the population). Thus 99.1 percent of constituencies provide no incentives for cross-ethnic voting. I break these 325 constituencies down by ethnic group in the last column of Table 4. One hundred eighty-four constituencies (58 percent) contained a Burman majority; forty-four (13 percent) a Shan majority, thirty-six (11 percent) a Karen majority, eighteen (4 percent) a Mon majority, eighteen ( 4 percent) a Rakhine majority, eleven ( 3 percent) a Kachin majority, eight ( 2.5 percent) a Chin majority, and six (1.8 percent) an Other majority.

The lightly shaded columns in Table 4 give more detail on the size of the majority group. In fact, the second column from the right shows us that 230 constituencies ( 70 percent) had majorities greater than 80 percent (this number includes the 42 percent monoethnic constituencies).

Next, I match these ethnic population estimates with the actual electoral results. Table 5 shows the results in the 184 Burman-dominated constituencies. First, all but two were won by one of the three parties dominated by ethnic Burmans, whether pro-junta, pro-NLD, or Third Way. Of these, 175 of 182 races (96 percent) were won by the military's 
Table 5 Electoral Results in Burman-Majority Constituencies

\begin{tabular}{lccc}
\hline Party Name & $\begin{array}{c}\text { \# of Seats } \\
\text { Won }\end{array}$ & $\begin{array}{c}\text { \% of Seats } \\
\text { (overall) }\end{array}$ & $\begin{array}{c}\text { \% of Seats in } \\
\text { Burman-Majority } \\
\text { Constituencies }\end{array}$ \\
\hline Chin Progressive Party & 1 & 0.52 & 0.52 \\
Independent & 1 & 0.52 & 1.05 \\
National Democratic Force & 8 & 4.19 & 5.24 \\
National Unity Party & 6 & 3.14 & 8.38 \\
Solidarity and Development Party & 175 & 91.62 & 100 \\
\hline
\end{tabular}

USDP. The two outlier constituencies were won by an independent candidate and the Chin Progressive Party; this inconsistency is likely due to data roughness such that the Chin Progressive Party likely won in a Chinmajority area.

In contrast, in the minority-dominant constituencies, shown in Table 6 , the USDP won only 59 percent of seats. This increases to 65 percent for all pro-junta parties if we include the National Unity Party (NUP). The National Democratic Force (NDF) - the main pro-NLD party - won no seats. What does this tell us about ethnicity and elections in Myanmar? First, it tells us something about the military. Assuming the elections are not free and fair, these results reflect the unwillingness of the military to overly falsify the voice of minority areas. The military even sponsored

Table 6 Electoral Results in Minority-Dominant Constituencies

\begin{tabular}{lrc}
\hline Party Name & \# of Seats Won & \% of Seats \\
\hline All Mon Region Democracy Party & 3 & 2.17 \\
Chin National Party & 1 & 0.72 \\
Chin Progressive Party & 1 & 0.72 \\
Elections canceled & 5 & 3.62 \\
Inn National Development Party & 1 & 0.72 \\
Kayin People's Party & 1 & 0.72 \\
National Unity Party & 8 & 5.8 \\
Pa-O National Organization & 3 & 2.17 \\
Phalon-Sawaw Democratic Party & 2 & 1.45 \\
Rakhine Nationals Progressive Party & 10 & 7.25 \\
Shan Nationals Democratic Party & 17 & 12.32 \\
Taaung (Palaung) National Party & 1 & 0.72 \\
Union Solidarity and Development Party & 82 & 59.42 \\
Unity and Democracy Party of Kachin State & 1 & 0.72 \\
Wa Democratic Party & 2 & 1.45 \\
Total & 138 & 100 \\
\hline
\end{tabular}


four ethnic parties to run in minority-dominant constituencies. ${ }^{28}$ There was clearly sensitivity, even in these restricted elections, to the voice of minority populations.

Despite the military's allowance of non-junta-aligned ethnic parties to win many seats in minority areas, the military still ensured it had a minimum number of votes in every constituency. This latter account is confirmed by hundreds of complaints expressed by minority parties. ${ }^{29}$ For example:

I think they planned before the election which seats they would give to the ethnic party candidates and which they would take for themselves. ... Whenever they didn't get the seats they wanted, they just used advance votes to beat the opposition candidates. (Chairman Ngwe Thein, All Mon Region Democracy Party [AMRDP])

I will still lodge complaints with the election commission about dishonest advanced ballots for the USDP and irregularities in vote counting. (Chairman Aye Maung, Rakhine Nationals Progressive Party [RNPP])

Thousands had to vote in advance [in Chin State] and all the votes went to the USDP. Many ballot boxes were not sealed after votes were cast. (Secretary Ceubikthawng, Chin National Party [CNP])

Given the propensity of voters in minority areas to vote for ethnic parties, it is not surprising that the main opposition party, the NDF, only ran candidates in five (3.5 percent) minority-dominated constituencies compared to fifty-one (28 percent) Burman-majority constituencies. ${ }^{30}$ This lends support to my prediction that were the military to allow completely free and fair elections, we would expect citizens in minority-dominant areas to vote for ethnic parties and not the NDF (and by extension the NLD) ${ }^{31}$

If we exclude USDP and NUP from the final calculations, we might get a better sense of what the results might look like if the elections were free and fair. Table 7 shows that most ethnic minorities will likely get close to the low end of their national proportion in the population. One group, the Rakhine, is already getting a percentage of seats similar to its population size. The Shan group in the scenario without USDP or NUP actually exceeds the top end of its population size. This is because there are many small ethnic groups living in Shan areas, so they take advantage of the plurality rule. This explains why the Other category remains low even after removing the USDP and NUP reported votes. In addition, elections were canceled in five constituencies where "Other" ethnic 
Table 7 Hypothetical Electoral Results in Minority-Dominant Constituencies

\begin{tabular}{lrrrr}
\hline $\begin{array}{l}\text { Minority } \\
\text { Ethnic } \\
\text { Group }\end{array}$ & $\begin{array}{c}\text { Predicted } \\
\text { Without USDP } \\
\text { (\% of all) }\end{array}$ & $\begin{array}{c}\text { Predicted } \\
\text { Without USDP } \\
\text { or NUP (\% of all) }\end{array}$ & $\begin{array}{c}\text { Actual } \\
\text { Seats }\end{array}$ & $\begin{array}{r}\% \text { Population } \\
\text { (National) }\end{array}$ \\
\hline Chin & $5(1.55 \%)$ & $6(1.86 \%)$ & $3(0.93 \%)$ & $2-6.3$ \\
Kachin & $1(0.31 \%)$ & $2(0.62 \%)$ & $1(0.31 \%)$ & $1.5-3.1$ \\
Karen & $8(2.48 \%)$ & $10(3.10 \%)$ & $6(1.86 \%)$ & $9-14.6$ \\
Mon & $6(1.86 \%)$ & $7(2.17 \%)$ & $3(0.93 \%)$ & $2-8$ \\
Rakhine & $10(3.10 \%)$ & $11(3.41 \%)$ & $10(3.10 \%)$ & $<5$ \\
Shan & $30(9.29 \%)$ & $38(11.76 \%)$ & $17(5.26 \%)$ & $3-5.5$ \\
Other & $5(1.55 \%)$ & $5(1.55 \%)$ & $3(0.93 \%)$ & $8-9$ \\
Total Minorities & $68(21.05 \%)$ & $45(13.9 \%)$ & $43(13.3 \%)$ & $32-45$ \\
\hline
\end{tabular}

groups constitute the majority. The Mon and Chin currently have about half the seats the low end of their population size suggests they should have. When we remove the USDP and NUP votes, however, parity is achieved.

The Kachin and Karen seat totals remain low even after removing the USDP and NUP votes. For the Kachin, this could be that those areas are so mixed that the military is afraid to report results anywhere near close to the actual ones, or that they just voted for the NDF, which took five seats in minority-dominant areas. The Karen are the most worrying. Most of the Karen seats came from parties that represent Karen subgroups. This does not bode well for the prospects of a united Karen party, but should not affect results to this extent. Farrelly $(2014,259)$ explains this result: "the Kayah state saw the re-monopolization of local power by the ... USDP [which] holds all 13 seats in the Kayah State Hluttaw, in an area where the residue of civil war lingers strongly." When something resembling normal politics resumes in Kayah state, there is nothing to suggest that the vote will not go to ethnic parties as it has in other minority states.

In sum, by excluding votes for military-affiliated parties (USDP and NUP), which I have claimed were manipulated, we can still learn much about the pattern of ethnic voting in Myanmar. The military gave away enough seats to provide hope, but not too many such that they would lose power. The military also appeared to be selective in how they reported the minority vote. It appears that they either underreported for the Karen and Kachin, perhaps seeing these two groups as politically problematic, or that these two groups might actually be attracted to nonethnic parties. 


\section{The 2012 By-Elections}

The Electoral Commission promised that the April 2012 by-elections would be fair, even indirectly acknowledging that the 2010 elections had not been so: "Forget the things that happened in the past and regard them as a lesson." ${ }^{2}$ Aung San Syu Kyi's NLD, which had boycotted the 2010 elections, ran against the military's USDP. The NDF also ran in opposition, but this was NLD's moment, winning in all thirty-seven constituencies up for grabs. The victory was hailed as a triumph of the people's voice, but what this fails to distinguish is which of the several peoples in Myanmar this was a victory for. In all but one of the thirty-seven constituencies, the majority Burmans constituted the largest ethnic group, still composing 45 percent in the remaining one.$^{33}$ In short, this was a victory of the Burman ethnic group against the military regime; the ethnic minorities were simply not a part of the picture. This pattern is similar to NLD's results in 1990, when elections were free and fair; even though minority groups were disorganized and suppressed, the NLD did not do well in ethnic minority constituencies (Farrelly 2014, 259; South $2008,118)$. As expected, minority parties did not contest in Burmandominated constituencies. Minority parties ran in only three districts in the 2012 by-elections - and they tended to be ones where minorities constitute significant portions of the constituency's population, even if there was no chance of winning. For example, in Kalaw, a constituency in the Shan state that borders prime Burman territory (the Mandalay division), Tais constitute 15 percent of the population and both the Shan Nationals Democratic Party and $\mathrm{Pa}-\mathrm{O}$ National Organization ran, coming in third and fifth, respectively. This seems to indicate that, even where they have no chance of winning a plurality, ethnic minorities will still vote for one of their respective ethnic parties. ${ }^{34}$

\section{Other Electoral Rules}

\section{Proportional Representation}

What would have happened under proportional representation? Let us first assume a single, national district. I tally votes by party at the national level and use the largest remainder method to calculate seats. Table 8 shows that for most groups there will be either no difference or just one difference. The group most affected by a single national PR system is the Shan, who would get eight fewer seats than they did under FPTP. This number might increase with the inclusion of the five constituencies 
where elections were canceled due to violence, but PR would still be less representative for the Shan. Karen parties get a couple fewer seats under single national PR, though were votes reported for the three uncontested seats won by the Pa-O National Organization, this might compensate for the discrepancy. Small minorities clearly do better under single national PR. They would win three to four more seats under PR than they did under FPTP. In short, while PR and FPTP do not produce identical results, FPTP is about the same for groups over 2 percent of the population. However, were we to include any threshold, which is common in PR systems, this representation advantage would disappear. In short, although we will have to wait for more accurate census data, as well as completely free and fair elections, this analysis suggests that there would not be much different outcomes based on the reported results in the 2010 elections.

Next, I consider PR in multiple districts. Since single national PR is rare empirically, this test is arguably more appropriate. While there are numerous ways to construct such districts, I do so around the existing state and district boundaries. Table 9 displays the success of minority parties under this hypothetical scenario. We see that these outcomes are even closer to those under FPTP. The Rakhine are now the only group that gets fewer seats than it did under FPTP. The Shan actually get one more, and again small parties are benefited by an additional three seats. Under both scenarios FPTP returns similar representation to PR. Under a single national district, minority parties actually get nine fewer seats. Under multiple PR districts, minority parties would gain just a single seat.

\section{Table 8 Comparison of Seats Under PR and FPTP, Single National District}

\begin{tabular}{lcccc}
\hline $\begin{array}{l}\text { Minority } \\
\text { Ethnic } \\
\text { Group }\end{array}$ & $\begin{array}{c}\text { Share of } \\
\text { Vote Under } \\
\text { FPTP }\end{array}$ & $\begin{array}{c}\text { Actual \# of } \\
\text { Seats Under } \\
\text { FPTP }\end{array}$ & $\begin{array}{c}\text { Predicted \# of } \\
\text { Seats Under PR }\end{array}$ & Difference \\
\hline Chin & 0.52 & 3 & 2 & -1 \\
Kachin & 0.11 & 1 & 0 & 0 \\
Karen & 1.4 & 6 & $4(7)$ & $-2(1)$ \\
Mon & 0.74 & 3 & 3 & 0 \\
Rakhine & 3.01 & 10 & 10 & 0 \\
Shan & 2.50 & 17 & $8(13)$ & $-9(-4)$ \\
Other & 1.45 & 3 & $6(7)$ & $3(4)$ \\
Total Minorities & 9.73 & 43 & 35 & $-9(0)$ \\
\hline
\end{tabular}

Notes: The Pa-O National Organization was uncontested in three constituencies and the Palaung National Party in one constituency. Official results do not list how many votes they got, so I simply add on those seats here in parentheses.

Elections were canceled in five constituencies in the Shan state because of continuing insurgency, indicating ethnic Shan strongholds. 
Table 9 Comparison of Seats Under PR and FPTP, Multiple Districts

\begin{tabular}{lccc}
\hline $\begin{array}{l}\text { Minority } \\
\text { Ethnic } \\
\text { Group }\end{array}$ & $\begin{array}{c}\text { Actual \# of Seats } \\
\text { Under FPTP }\end{array}$ & $\begin{array}{c}\text { Predicted \# of Seats } \\
\text { Under PR }\end{array}$ & Difference \\
\hline Chin & 3 & 4 & 1 \\
Kachin & 1 & 0 & -1 \\
Karen & 6 & 6 & 0 \\
Mon & 3 & 6 & 0 \\
Rakhine & 10 & 8 & -2 \\
Shan & 17 & 18 & 1 \\
Other & 3 & 6 & 3 \\
Total Minorities & 43 & 45 & 1 \\
\hline
\end{tabular}

There is, of course, much more complexity to both the simple FPTP and PR systems examined thus far. I have already mentioned how a threshold under PR would eliminate the gains for the smallest ethnic groups that I presented in Tables 8 and 9 . Such internal variety as well as interaction with other institutions and country-specific factors will surely lead to more variety in outcomes, but are not within the scope of the current study.

\section{The Alternative Vote}

Reilly and Nordlund (2008) have emphasized that AV works better in heterogeneous societies while single transferable voting (STV) is better for homogeneous ones. However, here I discuss how this further depends on how the ethnic groups are geographically distributed. Predicting what might happen under AV is difficult since such an analysis requires assuming which candidates might run, or how they would adjust their campaign rhetoric. In addition, we have to make a decision between strategic versus sincere voting. The most important statistics to reiterate here, however, are that 42 percent of constituencies are composed of a single ethnic group, and an additional 57 percent contain a majority ethnic group (i.e., more than 50 percent of the population). Thus, assuming citizens vote for a candidate from their ethnic group, there are no incentives for moderation, which stem from ranking members of other ethnic groups. The one place where it might make some difference is if the majority ethnic group has two competing candidates. Here, minority groups within a constituency could help elect the more moderate of the two. This could potentially affect 57 percent of constituencies, and while it would not change the ethnic makeup of parliament, it could change the voices within. But what if the NLD dominates elections as it did in 1990? Or 
what if Burman-dominated parties have regional strength? There are a lot of assumptions we have to make for this mechanism to work, not least of which is a fifty-fifty split of strength within each constituency. There might be no incentives for reaching out to minority groups in the short term.

\section{Geographic Distribution Requirement}

Myanmar's close neighbor, Indonesia, has important lessons for any discussion on electoral reform. With ethnic groups similarly geographically segregated, one goal of the electoral rules in the post-Suharto era was to prevent the formation of ethnic parties. Indonesia had experienced a wave of ethnic violence in the late 1990s and 2000s, which threatened to crystallize ethnic divides into the nascent democracy. To be sure, the salience of ethnicity is much higher in Myanmar and that might be a factor in the willingness of minorities to adopt these rules in the first place, but if the eradication of ethnicity from the party system is a desired goal-and Myanmar's first democratic era suggests it might be-then the Indonesian model provides an example.

In 1999, the country's second president and thirty-year dictator, Suharto, fell in the wake of the Asian financial crisis. In the euphoria of the regime change, Indonesia chose a proportional representation system to conduct elections. The districts were drawn around the country's twenty-seven provincial lines and ranged in magnitude from four seats (Papua) to eighty-two seats (East Java). The constitutional framers, however, saw fit to implement an additional requirement: political parties had to establish branches in more than half of all provinces. If this requirement alone was not onerous, parties also had to establish branches in half of all the regencies and municipalities within these provinces. Mathematically, this entailed branches in just over a quarter of Indonesia's administrative systems.

Although 181 parties registered to run in the 1999 elections, only 48 parties qualified (Johnson 2001). Most ethnic groups made no attempt to form a party, the rules simply being too restrictive. Looking at the two ethnic groups that are geographically dispersed, the Chinese and Javanese, we can see how the rules might restrict the Burmans in Myanmar.

Three Chinese parties registered in the 1999 elections: Partai Bhineka Tunggal Ika Indonesia (PBI), Reformasi Tionghoa Indonesia (RTI), and Partai Pembaruan Indonesia (PPI). ${ }^{35}$ Sujarwoko (2008) argues that these parties "failed to attract the sympathy and support of the Chinese" as most Chinese voted for the major multiethnic parties. Of the three, only the PBI made the final forty-eight cut and succeeded in at- 
tracting just 364,291 votes, or one-third of 1 percent of the vote. Despite being geographically dispersed across Indonesia, the Chinese could not meet the intraprovincial registration requirements due to their heavy concentration in urban areas. As Sujarwoko writes, "It is then very difficult for the Chinese parties to have branches in the sub-district level since more than half of the sub-districts are in rural areas." PBI failed to make the cut in the 2004 elections. $^{36}$

Intraregional distribution also prevents the Javanese, the country's largest ethnic group at 41.7 percent ( 2010 Census), from creating an ethnic party. The Javanese can be found in every province of Indonesia; they constituted over 25 percent in one-third of districts in 1999 and over 10 percent in 60 percent of districts. Though there are no data on ethnic groups at the subprovincial level, a good number of transmigrants have ended up in urban areas. Officially, the goal of the transmigrasi program was to resettle landless farmers, mostly from Java, to rural areas in the outer islands. Otten (1986), however, writes that program officers often encouraged urban people without jobs to move to transmigration settlements, that agriculture endeavors often failed, and that rates of migration to urban areas far exceeded those of the transmigrasi program. In addition, spontaneous migration (mostly non-Javanese) has been estimated to be twice as high over the same period, most of which was to urban areas (Abdullah 2009). In Western Papua, which has seen the largest transmigration in proportion to the native population, most of the migration has been to urban areas or those abandoning rural transmigration sites (Bertrand 2004). Thus, since over half the subdistricts are rural, it would have been difficult (though perhaps not impossible) for a Javanese party to meet the party registration requirement in 1999. Unlike the Chinese, the Javanese have not attempted to create a political party, so the nonformation of a Javanese party is not solely determined by the electoral rules.

For the 2004 elections, parties that contested the previous elections had to meet stricter geographic representativeness requirements or be forced to merge or form a new party. These requirements were to either hold 2 percent of the lower house (DPR) seats, or 3 percent of local government council (DPRD) seats in either half of the provinces, or half of the regencies/municipalities. This requirement was strictly enforced. New parties were subject to even stricter registration requirements than the previous elections. Parties were now required to have not just branches, but executive committees and permanent offices in two-thirds of the provinces and two-thirds of the regencies/municipalities. In addition, parties had to have membership of either 1,000 members or 0.001 
of the population in each regency/municipality where the party was organized, with membership cards as physical evidence (IFES 2003). The Indonesian electoral commission (KPU) seems to have been extremely diligent in enforcing the requirements for new parties. For the 2004 elections, only six parties qualified as existing parties, and an additional eighteen met the stringent registration conditions, for a total of twentyfour (Sherlock 2004).

Notably, none of these twenty-four parties were ethnic or regional in nature; the successful parties that were able to attract a significant spread of votes across Indonesia were the broad-based national parties. While there were discernible regional voting patterns (the Islamic parties dominated in Sumatra, PDI did best in Java/Bali, while GOLKAR remained strong in eastern Indonesia), the major parties won significant support in all areas of the country (Reilly 2011b). Several of the parties disqualified by the KPU were ethnic in nature, including the PBI (Chinese) and three Christian parties. ${ }^{37}$

In 2009, again no regional parties contested the legislative elections. Indeed, most of the debate surrounded the requirement for parties to have lists composed 30 percent of women and the switch to a more open list system to reduce party control. It seems as if the Indonesian electoral system has successfully rooted out ethnicity from the party system. Again, this is not to say that ethnic conflicts do not exist in Indonesia; they do in abundance. However, these conflicts have not been "particized." The electoral law has successfully avoided such dynamics, not by ensuring equal ethnic representation; not by reserving seats for each ethnic group; not by explicitly banning ethnic parties; not by requiring parties to be "national" in nature; but once again with party registration rules that effectively force parties to be broad-based and multiethnic.

The stricter party registration requirements post- 2004 made it even more difficult for Chinese and Javanese parties to form. No ethnic Chinese party qualified for the stricter final twenty-four cut in the 2004 elections (Sujarwoko 2008). The Javanese may be sufficiently dispersed to have mustered the registration of a party in 2004 and 2009, but it would have been much more difficult. ${ }^{38}$

Under similar rules, the Burmans would be forced to reach out to all the ethnic minorities in Myanmar as the Javanese have in Indonesia. Although the minorities would not get their own party, they would be a veto player within any winning party, thus forcing the Burman-dominated parties to moderate and cooperate prior to elections. These electoral rules would not even require the Burmans to split into two parties, although this would be more likely under these rules; even a party capturing all of 
the Burman vote would have to reach out to the minority groups. The rules could even require parties to register or gain a certain amount of support in every state, thus forcing parties to reach out to all the main minority groups. Electoral results during the democratic era would have been considerably different. Burman leaders would have been forced to reach out to leaders from the Karen and Shan ethnic groups. If Myanmar is ever to succeed as a democracy it must seriously consider the success of its Southeast Asian neighbor.

Geographic distribution requirements have not been widely adopted around the world. Nigeria used this requirement to abate the once salient ethnic divisions in that country (Horowitz 1985). Kenya used it with less success, and an important rule would be how to resolve outcomes where no party can achieve whichever requirements are imposed. Certainly, more work needs to be done to understand when the rule succeeds, but it offers a potential solution for Myanmar.

\section{Conclusion}

Theoretically, this analysis has supported the hypothesis that PR and FPTP would result in similar outcomes in ethno-geographically segregated societies. Looking at the experience of Myanmar in its democratic era (1948-1962), I showed that strong ethnic voting patterns led to the emergence of large congress parties (unstable multiethnic parties) and small ethnic parties that squabbled over the distribution of resources in the legislature. In short, FPTP led to the same negative outcomes attributed more generally to PR. In addition, although not free and fair, the 2010 elections demonstrate that Myanmar's political system continues to lack incentives for interethnic voting and more stable pre-electoral coalitions demonstrating compromise and restraint. However, I have shown that a switch to PR would have resulted in very similar outcomes.

It is thus surprising that PR continues to be attributed to success in abating ethnic conflict. The handbook on electoral system design by the International Institute for Democracy and Electoral Assistance (IDEA), which has much influence in policy circles, states, "The experience of a number of new democracies (e.g., South Africa, Indonesia, Sierra Leone) suggests that List PR gives the political space which allows parties to put up multiracial, and multi-ethnic, lists of candidates." Later on, another author in the same handbook posits that FPTP would "certainly fail to reflect the diversity of Indonesia." However, as the experience of Myanmar shows, FPTP in a country with high ethno-geographic segregation would lead to adequate reflection of diversity in the legislature. 
But that is precisely the problem: representation alone with no incentives to coordinate into pre-electoral coalitions based on moderation and compromise would be equally disastrous as PR with no such incentives.

In contrast, Indonesia's mosaic is held together today not because of PR but in spite of it. Indonesia employs a rare electoral rule, a "geographic dispersion requirement" that mandates parties gain a certain level of support across the country, either in terms of party membership and registration or in the actual vote (Reilly 2003; Tan 2002; Selway 2015).

This does not mean that there are no incentives for alliance-making under PR. All legislatures, regardless of their electoral rules, by nature of their majority rules in policymaking, offer some incentives for the aggregation of political groups. Moreover, PR with small district magnitude, especially two- or three-member districts, can exhibit similar dynamics to majoritarian rules.

More generally, however, the approach in this article demonstrates the need for a richer theory of electoral rules that takes social structure into account. ${ }^{39}$ This context conditionality is a fruitful avenue for future research in the discipline. In this article, I explored the implications of electoral rules in ethno-geographically segregated countries. What might happen under different configurations? Consider countries in which groups are perfectly intermixed throughout the country such that in every electoral district the relative size of ethnic groups is identical. The danger of an FPTP system would be the complete domination by a single ethnic group; there would be no incentives for cross-district coordination. PR, while not able to induce cross-ethnic voting, would at least enhance group representation. In countries where ethno-geographic segregation is intermediate, the potential disproportionality under FPTP can be resolved with cross-ethnic voting, as I (Selway 2015) have shown in the case of Mauritius. A richer theory might go even further to explore sizes of ethnic groups, how the largest or second-largest groups are geographically distributed, and so forth.

In such an effort, the method introduced in this article of using geographic information systems software to map electoral boundaries onto demographic maps in order to calculate the pattern of ethnic residence among constituencies is a useful tool in predicting more precise dynamics among ethnic groups in any proposed electoral system. The data I have used are somewhat crude, and I await the (hopefully) more accurate census data in Myanmar, but they reveal the potential of such an approach done on a cross-country basis. A dataset of this nature could test these theories more systematically, allowing us to hone in on cutoff points for preferring one system over another. On this front, two recent 
works, Lublin (2014) and Selway (2015), take such a large-N enterprise seriously, both of which echo the conclusions from the Myanmar case.

Joel Selway is associate professor of political science at Brigham Young University. $\mathrm{He}$ received his $\mathrm{PhD}$ from the University of Michigan. His research interests focus on ethnically divided societies, especially how to design democratic institutions to prevent conflict and enhance coordination over public goods provision. His new book, Coalitions of the Well-Being: How Electoral Rules and Ethnic Politics Shape Health Policy in Developing Countries, is forthcoming with Cambridge University Press.

\section{Notes}

1. Though electoral reform has been discussed for a couple of years now, the upper house voted to discuss it officially in parliament. "Burma to Consider Proportional Representation." Democratic Voice of Burma. June 5, 2014. www.dvb.no/news/burma-to-consider-proportional-representation-burma-myan$\operatorname{mar} / 41262$.

2. Consensus and majoritarian are Lijphart's (1990) terms. Consensus is sometimes referred to as consociational. I focus just on the electoral rules, although some scholars posit that the consensus/consociational argument involves a package of inseparable institutions, and, perhaps most importantly, elite cooperation (Andeweg 2000).

3. Other tools include grand coalition cabinets, minority veto powers, and communal autonomy.

4. Recently, Huber (2012) has argued that PR actually breaks down ethnic voting because it allows the creation of multiple parties that can target members of the same group on issues unrelated to group identity.

5. The country adopted the English name of Burma from Britain following independence. This was changed in 1989 by the military government to Myanmar. For consistency, I use its current name throughout this article.

6. I follow the Polity IV coding of Myanmar during this entire era as a democracy. Despite a brief military period in the years 1958-1960, this was at the invitation of the ruling party and thus Myanmar is coded as an 8 on a scale of -10 to 10 ( 10 being the most democratic) for this entire period.

7. Another recent study (Moser and Scheiner 2012) argues that a country's level of economic development causes electoral rules to have varying effects on the number of parties.

8. In a reply to Barkan, Reynolds (1995) claims that the cases Barkan uses are outliers and that majoritarian electoral rules still do not guarantee proportionality where voting patterns are geographically concentrated.

9. These are the most explicit studies on ethno-geographic segregation, though others have clearly been cognizant that how ethnic groups are geographically distributed will affect the choice of electoral rules; see Bogaards (2003, 2008), Horowitz (1994), and Reilly (2011b). Indeed, to be fair to Lijphart, he also suggests various combinations of political institutions given a 
country's social structure. However, he does seem firm on his electoral rule recommendation.

10. Other outcomes are possible in the more common case of nonidentically distributed constituencies, including the largest group's being uncertain of victory (Selway 2015).

11. It is not my intention to argue that FPTP and PR will lead to identical outcomes. For example, a PR system also represents geographically scattered minorities (that meet a certain legal or "effective" threshold). There are also concerns about competing parties from the same ethnic group and the underrepresentation of those who vote for the loser in their district. Lastly, FPTP also hides the fact that many groups that have no chance at winning may not even enter, and therefore earn no votes. I thank an anonymous reviewer for emphasizing these caveats.

12. This estimate is based on several sources: first, the 1931 census, which puts Burmans at 65 percent of the population. This figure, however, includes the Rakhine ethnic group, which most scholars estimate at about 3.5-6 percent of the population. The higher estimate of the Rakhine comes from the Joshua Project as a percentage of the official population. Martin Smith (1999) estimates the Rakhine population at 2.5 million of 48 million, or about 5 percent. The lowest number for the Burmans comes from taking all the leaders' estimates of their ethnic groups at face value and subtracting them from a population of 48 million (Smith 1999, 29-30). A detailed review of the 1931 census can be found in Enriquez (1933).

13. These ranges are based on several sources: CIA World Factbook (2011), Martin Smith (1999), the Official 1931 Census in Enriquez (1933), Ethnologue (Lewis 2009), Joshua Project (US Center for World Mission 2011), Tinker (1967), and Lintner (2003).

14. Though within each of these major ethnic families there is internal diversity, the macro identities are meaningful. Though many of these ethnic groups share the Buddhist religion (80-90 percent of the total population), ethnicity has remained the salient divide. Three of the major groups, moreover, have significant Christian populations: Kachin (64 percent), Chin (59 percent), and Karen (51 percent).

15. The Shan saw uniting with the Burmans as a better option than remaining under the British with no guarantees of independence. The Chin and Kachin were also in weak bargaining positions, having been financially dependent on Burma Proper in the past.

16. To use Gunther and Diamond's (2003) term, the AFPFL was a congress party. A congress party at first glance looks like a multiethnic party: its membership is open to all ethnic groups and it maintains a broad objective of national harmony rather than division. However, it remains internally fragmented. The component ethnic factions remain distinct both nominally and effectively, demanding proportional shares of party and government posts as well as patronage and other benefits. These ethnic factions often move in and out of the party with ease. Thus, as Gunther and Diamond $(2003,185)$ put it, "its very breadth renders it vulnerable to fracture along ethnic or regional lines." The raison d'être of each ethnic party does not diminish and frustration with the arrangement often leads 
to conflict, as we will see with the AFPFL. Congress parties tend to be very large, dominating the legislature; in effect this means that the legislative dynamics of ethnic conflict simply occur within the party. Moreover, other parties in the system tend to be monoethnic.

17. Sources vary on the precise number of seats for various parties. Silverstein $(1956,68)$ cites two sources; the higher estimate for the AFPFL agrees with Nohlen, Grotz, and Hartmann (2001).

18. The state territory was smaller than the militant Karen National Union had de facto control over.

19. Contests were not held in nine constituencies.

20. Detailed election results from Silverstein (1956).

21. The Arakanese had seventeen members in the previous election. In 1956, three Arakanese MPs were AFPFL affiliated. It is likely that the "missing" nine Arakan MPs ran as independents (indeed nine independents are listed as running and being in the opposition).

22. In the midst of a particularly heated debate, a Burman finance minister once referred to the AFPFL as an elephant and an opposition Arakanese MP as an ant and said, "when the big elephant passes urine the ant will suddenly feel its great impact and will be frightened, alarmed and scared" (M. M. Gyi 1983).

23. For almost 200 firsthand accounts of electoral fraud, see statements gathered by Altsean-Burma: www.altsean.org/Research/2010/Resources/Statements /Parties.php?pageNum_rs_statements $=0$.

24. These classifications are based on www.altsean.org/Research /2010/Key\%20Facts/PoliticalParties.php.

25. Englehart (2012) writes that NUP represents a faction within the military that is "dominated by networks linked to the now-deceased Ne Win rather than to Than Shwe."

26. Others included the Democratic Party (Myanmar), the Difference and Peace Party, the National Democratic Party for Development, the National Political Alliances League, and the Wunthanu NLD.

27. Imagine the electoral districts are mapped on a piece of transparent paper and put on top of the ethnic group map.

28 . Farrelly $(2014,259)$ notes that both the USDP and NLD are making sincere efforts to woo minority votes. The NLD "now has hundreds of local-level representative offices" in minority areas. The USDP "benefits from the influential role of the military in political and economic circles."

29. For a list of similar complaints see www.altsean.org/Research/2010 /Resources/Statements/Parties.php?pageNum_rs_statements=1 .

30. The NDF ran the following number of candidates in minority states: Arakan state (two candidates out of a total of seventeen available seats, 2/17) both majority Rakhine, but Sandoway is a border constituency; Chin state (2/9) - Paletwa is split fifty-fifty between Chin and Arakan, Matupi is 25 percent Burman; Kachin (2/18)-Myitkyina is majority Burman, Hpakant is 20 percent non-Kachin; Karen (0/7); Karenni (0/7); Mon (1/10)-Mudon is mixed Burman and Mon; Sagaing division (3/37) - Chaung U, Kawlin, and Monywa are 100 percent Burman; and Shan (0/55). 
31. A large factor for the low number of minority constituencies in which UDF chose to run was simply the cost - both upfront and postelection penalties for losing seats. However, this forced UDF to choose which constituencies it was most likely to win, demonstrating an ex-ante understanding of the party's weaker support in minority regions. I thank Dominic Nardi for this point.

32. Shwe Yinn Mar Oo, "EC Boss Pledges Free, Fair By-Elections," Myanmar Times, December 19-25, 2011.

33. They were joint largest in four constituencies.

34. This is also seen in the 1990 elections. Although the NLD seemed to have quite broad support, this masks the very low turnout in minority areas where minority ethnic parties did the best: explicit minority parties won sixty-eight seats in 1990 , or 14 percent of all seats.

35. Sujarwoko gives the English names of the first two of these parties as the Indonesian University in Diversity Party and the Chinese Indonesian Reformation Party, respectively.

36. Another reason why Chinese parties have not been successful is the internal diversity of the Chinese. Differences in terms of length of stay in Indonesia, place of settlement in the archipelago, place of origin, linguistic affiliation, and religious denomination weaken the ethnic group (Suryadinata 2008). A second possible reason that Chinese parties have not been successful in the postSuharto era is the eradication of institutionalized discrimination (Suryadinata 2008). The Habibie administration eased restrictions on Chinese schools, associational activity, Chinese media, and the celebration of Chinese culture more generally (Suryadinata 2008). It is not my intention, however, to argue that electoral rules were the only reason for the failure of Chinese parties.

37. "13 Parties May Be Unable to Contest 2004 Elections," Jakarta Post, November 29, 2003.

38. See Selway (2015) for an in-depth analysis of the Indonesia case.

39. Other contextual features are undoubtedly important. For example, other scholars have suggested that timing is important and that PR electoral rules lead to more peaceful democratic transitions in postconflict periods (Joshi 2013).

\section{References}

Abdullah, Taufik. 2009. Indonesia: Towards Democracy, History of Nationbuilding Series. Singapore: Institute of Southeast Asian Studies.

Amorim Neto, O., and Gary Cox. 1997. "Electoral Institutions, Cleavage Structures and the Number of Parties." American Journal of Political Science 41: 149-174.

Andeweg, Rudy B. 2000. "Consociational Democracy." Annual Review of Political Science 44, 3: 509-536.

Barkan, Joel D. 1995. "Elections in Agrarian Societies." Journal of Democracy 6, 4: 106-116.

- - . 1998. "Rethinking the Applicability of Proportional Representation for Africa." In Elections and Conflict Management in Africa, ed. Timothy D. Sisk and Andrew Reynolds. Washington, DC: US Institute of Peace Press. 
Bertrand, Jacques. 2004. Nationalism and Ethnic Conflict in Indonesia. New York: Cambridge University Press.

Bogaards, Matthijs. 2003. "Electoral Choices for Divided Societies: Multi-Ethnic Parties and Constituency Pooling in Africa." Commonwealth and Comparative Politics 41, 3: 59-80.

- _ . 2008. "Comparative Strategies of Political Party Regulation.” In Political Party Regulation in Conflict-Prone Societies, ed. Ben Reilly, Edward Newman, and Per Nordlund, 48-66. Tokyo: United Nations University Press.

Brambor, Thomas, William Roberts Clark, and Matt Golder. 2007. "Are African Party Systems Different?" Electoral Studies 26: 315-323.

Cady, John. 1958. A History of Modern Burma. Ithaca, NY: Cornell University Press.

Callahan, Mary P. 1998. "On Time Warps and Warped Time: Lessons from Burma's Democratic Era.” In Burma: Prospects for a Democratic Future, ed. Robert I. Rotberg. Washington, DC: Brookings Institution Press.

Central Intelligence Agency. 2011. World Factbook. US Government. https://www.cia.gov/library/publications/resources/the-worldfactbook/index.html.

Chit, Salai Myo. 2014. “Myanmar's Electoral System: Towards Proportional Representation." Alumni Research Papers, Educational Initiatives. Myanmar.

Clark, William, and Matt Golder. 2006. "Rehabilitating Duverger's Theory." Comparative Political Studies 39, 6: 679-708.

Cox, Gary. 1990. "Centripetal and Centrifugal Incentives in Electoral Systems." American Journal of Political Science 34, 4: 903-935.

_- - 1997. Making Votes Count: Strategic Coordination in the World's Electoral Systems. New York: Cambridge University Press.

Diamond, Larry. 1999. Developing Democracy: Toward Consolidation. Baltimore: Johns Hopkins University Press.

Duverger, Maurice. 1954. Political Parties. New York: Wiley.

Englehart, Neil A. 2012. "Two Cheers for Burma's Rigged Election." Asian Survey $52,4: 666-686$.

Enriquez, C. M. 1933. "Races of Burma." In Handbook for the Indian Army. Delhi: Government of India.

Farrelly, Nicholas. 2014. "Cooperation, Contestation, Conflict: Ethnic Political Interests in Myanmar Today." South East Asia Research 22, 2: 251-266.

Gunther, Richard, and Larry Diamond. 2003. "Species of Political Parties: A New Typology." Party Politics 9, 2: 167-199.

Gyi, M. M. 1983. Burmese Political Values: The Socio-Political Roots of Authoritarianism. Westport, CT: Praeger, p. 134.

Horowitz, Donald L. 1985. Ethnic Groups in Conflict. Berkeley: University of California Press.

- - . 1994. "Democracy in Divided Societies." In Nationalism, Ethnic Conflict and Democracy, ed. Larry Diamond and Marc F. Plattner. Baltimore: Johns Hopkins University Press.

Huber, John. 2012. "Measuring Ethnic Voting: Do Proportional Electoral Laws Politicize Ethnicity?" American Journal of Political Science 56, 4: 986-1001. 
International Foundation for Electoral Systems (IFES). 2003. "Overview of Legal Framework for 2004 General Elections in Indonesia." www.ifes.org /publication/10388092cda9308e65938065d0782b24/Election_Law_Summary.pdf.

Jarstad, Anna K. 2008. "Power Sharing: Former Enemies in Joint Government." In War-to-Democracy Transitions: Dilemmas of Peacebuilding, ed. A. K. Jarstad and T. D. Sisk. Cambridge: Cambridge University Press.

Joshi, Madhav. 2013. "Inclusive Institutions and Stability of Transition Toward Democracy in Post-Civil War States." Democratization 20, 4: 743-770.

Lewis, M. Paul. 2009. Ethnologue: Languages of the World. 16th ed. Dallas: SIL International. www.ethnologue.com.

Lijphart, Arend. 1990. "The Power-Sharing Approach.” In Conflict and Peacemaking in Multiethnic Societies, ed. Joseph V. Montville. Lexington, MA: Lexington Books.

- - - 2004. "Constitutional Design for Divided Societies." Journal of Democracy 15, 2: 96-109.

Lintner, Bertil. 2003. "Myanmar/Burma." In Ethnicity in Asia, ed. Colin Mackerras. New York: RouteledgeCurzon.

Lublin, David. 2014. Minority Rules: Electoral Systems, Decentralization, and Ethnoregional Party Success. New York: Oxford University Press.

- - . 2015. "Electoral Systems, Ethnic Heterogeneity, and Party System Fragmentation." British Journal of Political Science. doi:10.1017 /S0007123415000137.

Maeda, Ko. 2013. "Electoral Systems and Representation of Geographically Concentrated Minorities." Paper presented at the annual meeting of the American Political Science Association, Chicago.

Marston, Hunter. 2013. "Myanmar's Electoral System: Reviewing the 2010 and 2012 Elections and Looking Ahead to the 2015 General Elections." Asian Journal of Political Science 21, 3: 268-284.

Moser, Robert G., and Ethan Scheiner. 2012. Electoral Systems and Political Context: How the Effects of Rules Vary Across New and Established Democracies. Cambridge: Cambridge University Press.

Mozaffar, Shaheen, James R. Scarritt, and Glen Galaich. 2003. "Electoral Institutions, Ethnopolitical Cleavages, and Party Systems in Africa's Emerging Democracies." American Political Science Review 97, 3: 379-390.

Nohlen, D., F. Grotz, and C. Hartmann. 2001. Elections in Asia and the Pacific: A Data Handbook: Volume I: Middle East, Central Asia, and South Asia. Oxford: Oxford University Press.

Ordeshook, Peter, and Olga Shvetsova. 1994. "Ethnic Heterogeneity, District Magnitude, and the Number of Parties." American Journal of Political Science 38: 100-123.

Powell, G. Bingham. 1982. Contemporary Democracies: Participation, Stability and Violence. Cambridge, MA: Harvard University Press.

Rae, Douglas W. 1971. The Political Consequences of Electoral Laws. New Haven: Yale University Press. 
Reilly, Benjamin. 2001. Democracy in Divided Societies: Electoral Engineering for Conflict Management. New York: Cambridge University Press.

- - . 2002. "Electoral Systems for Divided Societies." Journal of Democracy 13, 2: 156-170.

- - . 2003. "Political Parties and Political Engineering in the Asia-Pacific Region." Asia Pacific Issues 71 (December): 1-8.

- - . 2006. Democracy and Diversity: Political Engineering in the Asia-Pacific, Oxford Studies in Democratization. Oxford: Oxford University Press.

- - 2011a. "Centripetalism." In Routledge Handbook of Ethnic Conflict, ed. Karl Cordell and Stefan Wolff. London: Taylor and Francis.

- - - 2011b. "Centripetalism." In Conflict Management in Divided Societies: Theories and Practice, ed. Stefan Wolff and Christalla Yakinthou. London: Routledge.

Reilly, Benjamin, and Per Nordlund. 2008. Political Parties in Conflict-Prone Societies: Regulation, Engineering and Democratic Development. Tokyo: United Nations University Press.

Reilly, Benjamin, and Andrew Reynolds. 1999. Electoral Systems in Divided Societies. Washington, DC: National Academy Press.

Reynolds, Andrew. 1995. "The Case for Proportionality." Journal of Democracy 6, 4: 117-124.

Roeder, Philip G., and Donald S. Rothchild. 2005. Sustainable Peace: Power and Democracy After Civil Wars. Ithaca: Cornell University Press.

Sahliyeh, Emile F. 1990. Religious Resurgence and Politics in the Contemporary World. New York: State University of New York Press.

SarDesai, D. R. 1997. Southeast Asia: Past and Present. Boulder, CO: Westview Press.

Sartori, G. 1986. "The Influence of Electoral Rules: Faulty Laws or Faulty Method?" In Electoral Laws and Their Political Consequences, ed. Bernard Grofman and Arend Lijphart. New York: Agathon Press.

Selway, Joel Sawat. 2015. Coalitions of the Well-Being: How Electoral Rules and Ethnic Politics Shape Health Policy in Developing Countries. New York: Cambridge University Press.

Sherlock, Stephen. 2004. The 2004 Indonesian Elections: How the System Works and What the Parties Stand For: A Report on Political Parties. Policy Papers on Political Governance 2004/1. Canberra: Centre for Democratic Institutions (CDI), Australian National University.

Silverstein, Josef. 1956. "Politics, Parties and National Elections in Burma." Far Eastern Survey 25, 12: 177-184.

Smith, Claire. n.d. "Adapting Consociationalism: Viable Democratic Structures in Burma." In Technical Advisory Network of Burma Working Paper. Washington, DC: The Burma Fund.

Smith, Martin. 1999. Burma: Insurgency and the Politics of Ethnicity. New York: Zed Books.

South, Ashley. 2003. Mon Nationalism and Civil War in Burma: The Golden Sheldrake. New York: Routledge. 
- - 2008. Ethnic Politics in Burma: States of Conflict. Abingdon, UK: Routledge.

Steinberg, David I. 1982. Burma: A Socialist Nation of Southeast Asia. Boulder, CO: Westview Press.

Stoll, Heather. 2008. "Social Cleavages and the Number of Parties: How the Measures You Choose Affect the Answers You Get." Comparative Political Studies 41, 11: 1439-1465.

Sujarwoko. 2008. "The Politics of Ethnic Discrimination and Resistance: The Chinese Ethnic in Indonesia, 1998-2008." Master's thesis. Institute for Social Studies. The Hague.

Suryadinata, Leo. 2008. Ethnic Chinese in Contemporary Indonesia. Singapore: Institute of Southeast Asian Studies.

Tan, Elaine Paige Johnson. 2002. "Streams of Least Resistance: The Institutionalization of Political Parties and Democracy in Indonesia." PhD diss., University of Virginia.

- -.2001 . "Political Parties and the Consolidation of Democracy in Indonesia." In Almanac of Indonesian Political Parties, 117-146. Jakarta.

Taylor, Robert H. 1987. The State in Burma. London: Hurst.

Taylor, Rupert. 2009. Consociational Theory. London: Routledge.

Tinker, Hugh. 1967. Union of Burma: A Study of the First Years of Independence. New York: Oxford University Press.

U Nu. 1975. U Nu Saturday's Son. New Haven, CT: Yale University Press.

US Center for World Mission. 2011. Joshua Project, Pasadena, CA.

Ziegfeld, Adam. 2013. "Are Higher-Magnitude Electoral Districts Always Better for Small Parties?” Electoral Studies 32, 1: 63-77. 